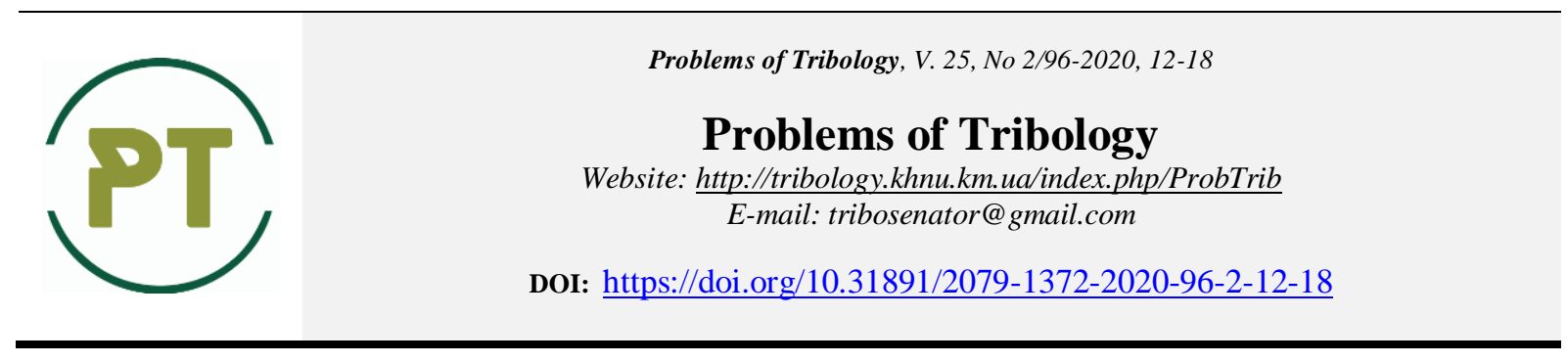

\title{
The equation of the entropy production in a tribounit
}

\author{
Ye.Ventsel", O. Shchukin, O. Orel, N. Saienko \\ Kharkiv National Automobile and Highway University, Kharkiv, Ukraine \\ *E-mail: alexhome88@gmail.com
}

\begin{abstract}
It is proposed to consider the tribounit as a non-equilibrium thermodynamic system in which entropy is produced. The corresponding equation is obtained, whose analysis shows that in order to bring the tribounit to a stationary state, in which the entropy production tends to zero, and there is a minimum of friction force and a wear rate, it is necessary to reduce the coefficient of dynamic viscosity of the lubricating medium, the speed of relative motion of tribo-surfaces, sizes of contaminant particles, etc.

As a result of laboratory studies, it has been established, in particular, that the presence of contaminant particles in the oil with the average weighted size of $10.36 \mu \mathrm{m}$ leads to a decrease in the oil temperature, the friction coefficient and wear of the tribo-surfaces compared to the oil in which the average weighted size of particles is $35.8 \mu \mathrm{m}$. This proves the original hypothesis of the article that the tribounit is a thermodynamic system in which entropy is produced, and to which the laws of non-equilibrium thermodynamics are applicable.
\end{abstract}

Keywords: tribounit; energy; entropy; particle; dissipative system, coefficient of friction; wear.

\section{Introduction}

When studying the processes of the tribounit friction and wear, it is necessary to consider it as a dynamic dissipative system in which the degradation of the energy of the macro-mechanical movement is realized, i.e., entropy is produced. In this regard, it is quite appropriate to use the basic law of non-equilibrium thermodynamics about the tendency to bring the entropy of a thermodynamic system to a minimum positive value when it approaches a stationary state, which is characterized by the constancy of all parameters of the system. As applied to the tribounit as an object of non-equilibrium thermodynamics, here we mean the friction force and the wear rate of tribo surfaces [1].

\section{Literature review}

Until now, tribounits have been mainly considered as a triad consisting of three components: the friction surface - the lubricating layer - the friction surface. This model of the tribounit is quite simple and relatively easy to study [2 - 4]. However, due to the expansion in the number of studies of the friction and wear processes with increasing thermal and mechanical loading of the tribounit, such a model is becoming insufficiently informative, which in turn requires a different, more modern approach to representing the processes of friction and wear during operation of machines.

In accordance with the model of L.I. Bershadsky [5] the tribosystem includes excited volumes of materials of friction surfaces and a lubricant layer, in which the positive entropy production is realized by any mechanisms.

The generalized equation for the production of entropy in the tribounit taking into account the properties of the lubricating medium was obtained by A.A. Litvinov and A.Ya. Shopel [6, 7]; however, most of the parameters included in this equation are implicit and complex functions. In this regard, an attempt was made to theoretically establish the role of such important parameters as the speed of relative motion of tribo surfaces, the coefficient of dynamic viscosity of the lubricating medium, the size and the number of mechanical particles as the tribosystem approaches a stationary state. 


\section{The purpose of the work}

The purpose of the work is to establish the equation for the production of entropy in tribounits taking into account a number of parameters characterizing them, and experimentally verify its validity.

\section{Presentation of research materials}

In accordance with the aforesaid, we analyze the evolutionary trend of various tribounit parameters when it approaches a stationary state, using I. Prigozhin's theorem [8].

According to this theorem, the entropy production tends to a minimum value when the system approaches a stationary state. Here we will keep in mind that it is always a positive value.

As it is known, a complete change in entropy $d S$ consists of a change in entropy produced inside the system and entropy caused by the external environment. Considering that the entropy production is a part of the total derivative of entropy with time:

$$
\frac{d S}{d t}=\frac{d_{i} S}{d t}+\frac{d_{e} S}{d t}
$$

where: $\frac{d_{e} S}{d t}=\frac{1}{T} \cdot \frac{d Q}{d t}$ is the flow of entropy.

When approaching a stationary state

$$
\frac{d S}{d t} \approx 0 ; \frac{d_{i} S}{d t}=-\frac{d_{e} S}{d t} \text { or } p_{S}=-\frac{1}{T} \cdot \frac{d Q}{d t}
$$

In accordance with the first law of thermodynamics

$$
d Q=d U-d A
$$

For a tribounit operating under the conditions of hydrodynamic lubrication, a change in the internal energy $d U$ is associated with a change in its temperature $d T$ and surface energy due to the presence of particles in the gap. That is

$$
d U=c \cdot m \cdot d T+\sigma \cdot d(\Omega N)
$$

where: $\mathrm{C}$ is the specific heat; $m$ is the mass of the substance in the gap of the tribounit; $\sigma$ is the specific surface energy; $\Omega$ is the average surface area of an individual particle in the gap; $N$ is the number of particles in the gap.

The work $d A$ performed by the force of viscous friction when moving the surfaces $\square S$ of the tribounit by the value $d l$ is equal to:

$$
d A=\eta \cdot \operatorname{grad}|\vec{v}| \cdot \Delta S \cdot d l
$$

where: $\eta$ is the coefficient of the oil dynamic viscosity.

Substituting (3) and (4) in (2) and (1), we obtain the following expression for the production of entropy:

$$
p_{S}=\frac{1}{T} \cdot\left[\eta \cdot \operatorname{grad}|\vec{v}| \cdot \Delta S \cdot \frac{d l}{d t}-c \cdot m \cdot \frac{d T}{d t}-\sigma \cdot \frac{d(\Omega N)}{d t}\right]
$$

As with approaching the stationary state the production of entropy tends to some constant positive value corresponding to its minimum, and all components in the right-hand side of expression (5) are independent of each other, each of these components should be constantly positive. Obviously, to fulfill this condition, it is necessary that

$$
\frac{d T}{d t} \square \leq 0
$$




$$
\frac{d(\Omega N)}{d t} \square \leq 0
$$

Inequality (6) describes the well-known fact of a decrease in the temperature of a tribounit when it approaches a stationary state.

To discuss the meaning of inequality (7), we express the surface area of a particle in terms of its average linear size $L$. It is obvious that

$$
\Omega=\zeta \cdot L^{2}
$$

where: $\zeta$ is the form factor, that is, the coefficient of proportionality depending on the shape of the particle (for example, for a rod with linear dimensions $L, L / 2$ and $L / 10, \zeta=1,3$ )

$$
\frac{d(\Omega N)}{d t}=\zeta \cdot L \cdot\left[2 N \cdot \frac{d L}{d t}+L \cdot \frac{d N}{d t}\right] \leq 0
$$

Due to the fact that $\left|\sigma \cdot \zeta \cdot L \cdot\left(2 N \frac{d L}{d t}+L \frac{d N}{d t}\right)\right|$ tends to the minimum value, the average particle size $L$ decreases, that is, $d L<0$.

Since (8) is transformed to the inequality

$$
\frac{d N}{d L} \leq-2 \frac{N}{L}
$$

then taking into account the sign of $d L$, we have

$$
-\frac{d N}{|d L|} \leq-2 \frac{N}{L}
$$

Whence it follows that

$$
\frac{d N}{|d L|} \geq 2 \frac{N}{L}
$$

As it can be seen from inequality (9), $d N>0$, that is, if the tribounit approaches the stationary state, the number of particles $N$ in the gap increases, and their average size $L$ decreases, and the smaller $L$ and the larger $N$ are, the closer the tribounit to the stationary state is.

Given that in (5) $-\frac{d l}{d t}=v$, and also replacing $-\frac{d(\Omega N)}{d t}$ in (5) in accordance with (8), we obtain:

$$
-P_{S}=\frac{1}{T} \cdot\left[\eta \cdot v \cdot \operatorname{grad}|\vec{v}| \cdot S-c \cdot m \cdot \frac{d T}{d t}-\zeta \cdot \sigma \cdot L \cdot\left(2 N \frac{d L}{d t}+L \frac{d N}{d t}\right)\right] .
$$

Taking into account that $\frac{d T}{d t}<0$ and $\frac{d(\Omega N)}{d t}<0$, the expression for the production of entropy in the final form is as follows:

$$
P_{S}=\frac{1}{T} \cdot\left[\eta \cdot v \cdot \operatorname{grad}|\vec{v}| \cdot \Delta S+c \cdot m \cdot\left|\frac{d T}{d t}\right|+\zeta \cdot \sigma \cdot L \cdot\left|2 N \frac{d L}{d t}+L \frac{d N}{d t}\right|\right] .
$$

As it can be seen from (10), minimizing the production of entropy, and hence the friction force and wear of the tribounit requires a decrease in the dynamic viscosity of the lubricating medium, and therefore, a decrease in the temperature gradient, a decrease in the speed of the relative motion of the tribo surfaces, and also the average weighted linear size $L$ of contaminant particles in the lubricating medium. 
Let us consider the experimental data related to the effect, for example, of the average weighted size of contaminant particles on the wear of tribo surfaces, that is, on their approaching to a stationary state. For this, wear tests were carried out on the SMC-2 and CHSHM friction machines.

On the SMC-2 friction machine, the "block - roller" test scheme (Fig. 1) was used, which provided the contact of the samples over the surface under a mixed (hydrodynamic and boundary) lubrication mode. The use of replaceable balls as wear elements on the ЧШМ friction machine (Fig. 2) makes it possible to obtain the contact of the friction surfaces at a point (boundary lubrication mode).

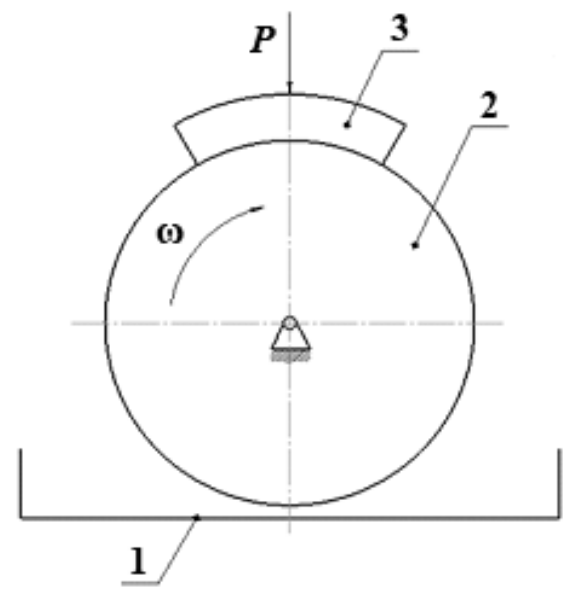

Fig. 1. Scheme of tests on the SMC-2 friction machine: 1 - cuvette with oil; 2 - roller; 3 - block

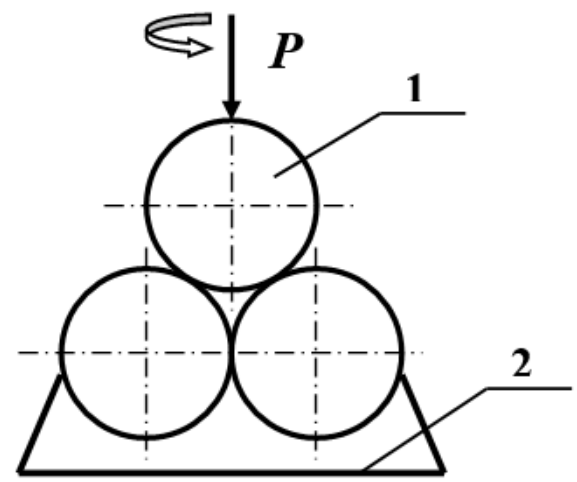

Fig. 2. Scheme of tests on the CHSHM friction machine: 1 - ball; 2 - cuvette with oil

To carry out tests, the I-G-A-32 oil was used, which worked in the hydraulic drive of the GR-165 motor grader for 640 machine-hours and had an average weighted size of contaminant particles of $35.8 \mu \mathrm{m}$. The same oil was also tested, but after artificial dispersion of contaminant particles using a hydrodynamic dispersant [9, $10]$, which reduced the average size of particles to 10.36 microns.

The following combinations of materials of samples were used on the SMC-2 friction machine during testing: BrAZH 9-4 bronze - 38HS steel, SHH15 steel - SHH15 steel, VCH cast iron - 18 HGT steel.

The test mode on the SMC-2 friction machine was as follows: the samples were tested without load for 15 minutes, the samples were tested under load of $300 \mathrm{~N}$ for 2 hours, and the tests were carried out under load of $600 \mathrm{~N}$ for 4 hours.

During the tests, the moment of friction was recorded using the PRS-1 potentiometer included in the machine set, and the oil temperature was recorded by means of a thermocouple installed in the bath at a depth of $5 \mathrm{~mm}$ below the oil level.

The wear of the pads and rollers was determined by establishing their loss of mass during the test period. Weighing was carried out with the VLA-200г-M analytical balance with an accuracy of $\pm 0.0001 \mathrm{~g}$ with bringing the samples to the constant weight.

On the CHSHM-1 friction machine, replaceable balls with a diameter of $8 \mathrm{~mm}$ made of SHH15 steel with a hardness of $62 \mathrm{HRC}$ were used as wear elements. 
The test mode was as follows: the load on the balls was $80 \mathrm{~N}$, the rotation speed of the upper hinge was 1 $\min ^{-1}$, the test time was 2 hours. During the test period, the moment of friction (in standard units) was measured, and at the end of the tests, the diameter of the wear spot was determined with the use of the MBS-9 microscope.

The replication of tests of each oil with each combination of materials of friction pairs on the SMC-2 and CHSHM-1 friction machines was chosen to be five, which, in accordance with the results of the explorary research allowed to obtain a fractional error of not more than 0.25 with a confidence factor of 0.9 .

The results of testing the I-G-A-32 oil on each friction machine are shown in tables 1 and 2.

Table 1

\section{Results of oil tests on the SMC-2 friction machine}

\begin{tabular}{|c|c|c|c|c|c|c|}
\hline \multirow{2}{*}{$\begin{array}{l}\text { Condition of the } \\
\text { I-G-A-32 oil }\end{array}$} & \multirow{2}{*}{$\begin{array}{c}\text { Materials } \\
\text { of roller and } \\
\text { pad }\end{array}$} & \multirow{2}{*}{$\begin{array}{l}\text { Coefficie } \\
\text { nt of } \\
\text { friction }\end{array}$} & \multicolumn{3}{|c|}{ Wear, g } & \multirow{2}{*}{$\begin{array}{l}\text { Temperature of } \\
\text { oil at the end } \\
\text { of the test }\end{array}$} \\
\hline & & & Pad & Roller & Total & \\
\hline $\begin{array}{l}\text { Worked with a } \\
\text { particle size of } \\
35.8 \text { microns }\end{array}$ & $\begin{array}{c}\text { BrAZH 9-4 - } \\
\text { steel 38XC }\end{array}$ & 0.0163 & 0.1420 & 0.0180 & 0.1600 & 352 \\
\hline $\begin{array}{l}\text { Worked with a } \\
\text { particle size of } \\
10.36 \text { microns }\end{array}$ & The same & 0.0135 & 0.0989 & 0.0120 & 0.1108 & 348 \\
\hline $\begin{array}{l}\text { Worked with a } \\
\text { particle size of } \\
35.8 \text { microns }\end{array}$ & $\begin{array}{l}\text { SHH-15 steel - } \\
\text { SHH -15 steel } \\
\text { SHH - } 15\end{array}$ & 0.0747 & 0.0015 & 0.0025 & 0.0040 & 357 \\
\hline $\begin{array}{l}\text { Worked with a } \\
\text { particle size of } \\
10.36 \text { microns }\end{array}$ & The same & 0.0692 & 0.0010 & 0,0017 & 0.0027 & 356 \\
\hline $\begin{array}{l}\text { Worked with a } \\
\text { particle size of } \\
35.8 \text { microns }\end{array}$ & $\begin{array}{c}\text { VCH cast iron - } \\
18 \mathrm{HGT} \\
\text { steel }\end{array}$ & 0.0715 & 0.0013 & 0.0035 & 0.0048 & 357 \\
\hline $\begin{array}{l}\text { Worked with a } \\
\text { particle size of } \\
10.36 \text { microns }\end{array}$ & The same & 0.0345 & 0.0439 & 0.0030 & 0.0469 & 355 \\
\hline
\end{tabular}

Table 2

Results of oil tests on the CHSHM -1 friction machine

\begin{tabular}{|c|c|c|}
\hline Condition of the I-G-A -32 oil & $\begin{array}{c}\text { The moment of friction forces, } \\
\text { standard units }\end{array}$ & $\begin{array}{c}\text { Diameter of the spot of } \\
\text { wear, mm }\end{array}$ \\
\hline $\begin{array}{c}\text { Worked with a particle size of } \\
35.8 \text { microns }\end{array}$ & 56.6 & 0.402 \\
\hline $\begin{array}{c}\text { Worked with a particle size of } \\
10.36 \text { microns }\end{array}$ & 28.8 & 0.315 \\
\hline
\end{tabular}

Note: Tables 1 and 2 show the average values for the results of five tests on the oil in each of its state.

As it can be seen from the data presented, the oil temperature, the friction coefficient (moments of force) and wear on both friction machines with different combinations of materials of samples are less when lubricating them with the I-G-A -32 oil with the average weighted size of particles of $10.36 \mu \mathrm{m}$ compared to the oil, in which the average weighted size of particles is 235.8 microns.

In the same way, the presence of contaminant particles in the oil with the average weighted size of 10.36 $\mu \mathrm{m}$ leads to a decrease in the oil temperature and friction coefficient, which is a direct indicator that the tribounit can be considered as a thermodynamic system, which under the certain conditions tends to an equilibrium state (approaching zero entropy production), that is, to minimizing friction and wear. 


\section{Conclusions} produced.

1. The tribounit can be considered as a non-equilibrium thermodynamic system in which entropy is

2. The obtained equation for the production of entropy in the tribounit shows that in order to bring it to a stationary state, which is characterized by the minimum of friction force and a wear rate, it is necessary to reduce the coefficient of dynamic viscosity of the lubricating medium, the temperature gradient, the speed of the tribo surfaces relative motion, and also the average weighted linear size $L$ of contaminant particles in the lubricating medium.

3. The results of wear tests on the friction machines have confirmed the validity of the obtained equation for the production of entropy, in particular, the fact that a decrease in the size of contaminant particles helps to reduce friction and wear of tribo surfaces, as well as the temperature of the lubricating medium.

\section{References}

1. Ye. Ventsel, O. Orel, O. Shchukin, N. Saienko, A. Kravets', Dependence of Wear Intensity on Parameters of Tribo Units, Tribology in Industry, Vol. 40, No. 2, pp. 195-202, 2018, DOI: 10.24874/ti.2018.40.02.03

2. Forbes E. Antiwear and extreme pressure additives for lubricants / E.Forbes // Tribology. -2008. vol.3. - №3. - Pp.145-152.

3. Akin L. An Interdiscipllinary Lubrication Theory for Gear / L.Akin // ASME Trans. - 1993. - B.36. №4. - Pp.1178-1195.

4. Kostetskiy B.I. Trenıe, smazka i iznos v mashinah / B.I. Kostetskii. - K.: Tehnika, 1970. - 396 p.

5. Bershadskii L.I. O vzaımosviazıah strukturnyh mehanizmov i dissipativnyh potokov pri kınetıcheskom (nekulonovskom) trenı i iznose // Trenie i iznos, 1989. - T.10, №2. - Pp.358-364.

6. Litvinov A.V. Obobennoe uravnenıe proizvodstva entropii $\mathrm{v}$ tribosistemah $\mathrm{s}$ uchetom svoistv smazochnoi sredy / A.V. Litvınov, A.Ia. Sheel // Issledovanie ekspluatatsionnyh svoistv AVIAGSM i spetsj1dkoste1. - 1987. - Pp.139-141

7 Osıpov A.I. Termodınamıka vchera, segodnıa i zavtra. Ravnovesnaia termodinamıka / A.I. Osipov // Sorosovskı1 obrazovatelnyi jurnal. - 1999. - №4, Ch.1. - Pp. 79-85.

8. Berezniakov A.I. Kompleksna1a strukturnaia prisposobliaemost tribosopriajenı1 v aspekte teoremy I. Prıgojına / A. I. Bereznıakov // Trenie i ıznos. - 1993. - T.14, №1. - Pp.194-202.

9. Ventsel E.S. Gidrodınamıcheskı1 dispergator dlia uluchsheniia svoistv smazochnyh masel / E.S. Ventsel // Mir tehniki i tehnologii. - 2003. - №7. - Pp. 42-43.

10. Ventsel E.S. Pidviennia iakosti mastil, paliv i tribovuzliv mashin : monografiia / E.S. Ventsel, O.V. Orel, O.V. Shchukin. - H.: FOP Brovin O.V., 2017. - 264 p. 
Венцель Є.С., Щукін О.В., Орел О.В., Саєнко Н.В. Рівняння виробництва ентропії в трибосполученні

Запропоновано розглядати трибосполучення як нерівноважну термодинамічну систему, в якій виробляється ентропія. Отримано відповідне рівняння, аналіз якого показує, що для наближення трибосполучення до стаціонарного стану, при якому виробництво ентропії наближається до нуля і має місце мінімум сили тертя і швидкості зношування, необхідно зменшення коефіцієнта динамічної в'язкості змазуючого середовища, швидкості відносного переміщення трибосполучення, розмірів частинок забруднень тощо. В результаті лабораторних досліджень встановлено, зокрема, що наявність в маслі частинок забруднень 3 середньозваженим розміром 10,36 мкм призводить в порівнянні 3 маслом, в якому середньозважений розмір частинок складає 35,8 мкм, до зменшення температури мастила, коефіцієнта тертя і зносу трибоповерхонь. Це підтверджує вихідну гіпотезу статті про те, що трибосполучення є термодинамічною системою, в якій виробляється ентропія і до якої застосовні закони нерівноважної термодинаміки.

Ключові слова: трибосполучення; енергія; ентропія; частка; дисипативна система, коефіцієнт тертя; знос 